\title{
UNA VISTA PANORÁMICA DE HUELGAS, MANIFESTACIONES Y MÍTINES EN CARAS Y CARETAS: PRENSA Y FOTOGRAFÍA A PRINCIPIOS DEL SIGLO XX EN ARGENTINA
}

\author{
Inés Yujnovsky*
}

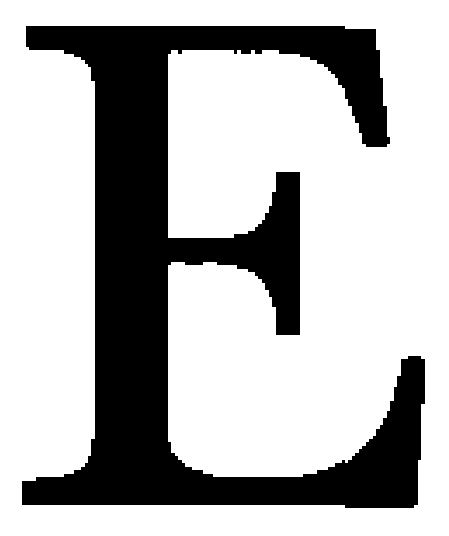

n este periodo la fotografía es un aspecto más de la modernización y las imágenes captadas se convirtieron en una forma de expresión que, gracias a los adelantos técnicos, se reveló como un medio propicio para registrar, seleccionar, configurar, determinar e imponer los acontecimientos significativos de la época. Las obras de gobierno, los actos públicos, las empresas y las elites que las estimulaban se fotografiaban para demostrar su ideología de progreso expansivo, la estabilidad y las posibilidades abiertas al talento. Sin embargo, este periodo de crecimiento económico no estuvo exento de conflictos y hacia ellos también se enfocaron los fotógrafos.

En este trabajo se expondrán algunas conclusiones preliminares relacionadas con el mundo del trabajo a principios del siglo Xx en Argentina, analizando fuentes fotográficas. Es importante señalar que al tratarse de un acercamiento novedoso al análisis de investigación histórica, las propuestas que se desarrollan aquí están en proceso de trabajo y pretenden ampliar las discusiones respecto al uso de la imagen en la investigación. A partir de un breve análisis de las fotografías, en tanto forman parte de las disputas por la definición de significados, se realizará una descripción de la diversidad de trabajadores participantes en huelgas y manifestaciones; se observan ámbitos de lucha, la importancia de la exposición pública de los reclamos, el papel de las mujeres y los niños y la existencia de códigos gestuales particulares. Finalmente se propone una

* El Colegio de México. 
periodización que divide un momento de afinidad y otro de aversión de la revista Caras y Caretas hacia los sectores obreros.

El conjunto de fuentes seleccionadas proviene del Archivo General de la Nación Argentina (AGN), incluye material procedente del fondo fotográfico de Caras y Caretas. Ésta fue una de las revistas ilustradas más importantes de la Argentina de la época. Se trata de una publicación quincenal que apareció entre los años 1898 y 1939 . Estaba destinada principalmente a los sectores medios, pero tuvo una amplia difusión entre otros grupos sociales. Incluía una gran diversidad temática que iba desde eventos sociales, novedades científico-tecnológicas hasta las páginas dedicadas al "mundo obrero". Contenía una gran cantidad de publicidad, pero su característica principal fue el humor político y nunca dejó de lado su participación en las contiendas para elecciones presidenciales. A diferencia de las publicaciones periódicas, la avanzada tecnología de la revista permitía reproducir fotografías que realizaba su propio equipo de fotógrafos.

El archivo fotográfico de Caras y Caretas fue donado al AGN. Como es frecuente, su orden es temático, por lo tanto hasta el momento no se ha podido identificar con precisión a los autores. ${ }^{1}$ Entre unas 1500 fotografías del periodo 1902-1919, se han seleccionado imágenes de manifestaciones, mítines y huelgas de diversos tipos de trabajadores: panaderos, peones, estibadores, cocheros, foguistas, empleados de tranvías, operarios del ferrocarril, tejedoras, zapateros, sastres, modistas, policías, personal de limpieza, inquilinos, estudiantes, entre otros. ${ }^{2}$ El trabajo de investigación se inició con la observación de las copias en papel que se encuentran en el AGN, la alta calidad fotográfica permitió la observación iconográfica con mucho detalle. Sin embargo, aunque las copias tienen marcas de edición como el recorte o el tamaño, no contienen referencias relacionadas con fechas y lugares, por lo tanto, en la etapa siguiente de la investigación se recurrió a la hemeroteca, ${ }^{3}$ se encontraron publicadas en

${ }^{1}$ En general aparece la referencia de "el equipo de fotógrafos de Caras y Caretas que podía llegar a incluir entre cinco y diez empleados. Se espera que nuevos trabajos puedan desentrañar este problema.

${ }^{2}$ Han sido valiosas las consultas en otros archivos que incluyen colecciones fotográficas de menor importancia cuantitativa. El Museo Ferroviario Nacional reúne variado material relativo a los ferrocarriles. La Dirección de Programas Internacionales de la Facultad de Arquitectura, Diseño y Urbanismo de la Universidad de Buenos Aires ha reunido fotografias para la exposición Buenos Aires 1910: Memoria del Porvenir. Han sido de utilidad las carpetas referidas a trabajadores y prensa e iconografía relevadas por Luis Príamo y Roberto Amigo, respectivamente. Se puede ver el catálogo Buenos, 2000 o Gutman, Buenos, 1999. El fondo fotográfico más importante del CEDINCI (Centro de Documentación e Investigación de la Cultura de Izquierdas en la Argentina) corresponde a Gráfica Política entre fines de los años 1960 y mediados de 1980, pero además incluye otras fotografias como las de una huelga en Dock Sud en 1918.

${ }^{3}$ La colección de Caras y Caretas se puede encontrar en la Biblioteca Nacional de Argentina y en el Colegio Nacional Buenos Aires. En México no pude hallar una colección de la revista. 
Caras y Caretas la mayoría de las fotografías y de esta forma se pudieron contextualizar las imágenes.

La consideración de la historia como discurso, lo explícito de las reglas de construcción de estos discursos y el énfasis en la diversidad de formas de interpretación estimularon la utilización de registros visuales. La constante confrontación entre objetividad y subjetividad, hecho e interpretación aparece en las fotografías. Las imágenes pueden ser utilizadas como registros del pasado; al igual que cualquier otro texto requieren una lectura crítica para reconstruir su sentido histórico. Mi interpretación pone especial atención en la construcción de las imágenes. Considero que los fotógrafos y también los actores sociales retratados eran conscientes del impacto que producía la imagen fotográfica, por lo tanto, no se puede tener una mirada ingenua pensando que ofrecen una "realidad" objetiva y espontánea. Es justamente el dominio de las escenas fotográficas lo que nos permite acercarnos a cierto universo propio de los trabajadores. ${ }^{4}$ De todos modos, las interpretaciones propuestas deberán ser profundizadas con la ayuda de nuevos datos historiográficos y fotográficos, así como de otros tipos de fuentes primarias y secundarias.

Las series fotográficas que se analizan en este trabajo no se detienen en individuos, sino que abarcan a grupos de trabajadores. Las fotografías exhiben comisiones de huelguistas en preparativos, a la espera o en la toma de decisiones y también, por qué no, posando para la fotografía. ${ }^{5}$ Algunas se asemejan a un retrato familiar, no faltan los niños ni las diferencias generacionales, sólo que estas familias se componen de compañeros trabajadores. También se registran los picnics obreros con payadas, tangos y charlas. ${ }^{6}$ Otras imágenes muestran la organización de los huelguistas como el reparto de comida, el despliegue, el movimiento y la lucha en las calles, o la soledad, quietud y vacío que producen las huelgas generales. No han de faltar los rompehuelgas y los patrones, la escolta policial para garantizar el orden, así como destrozos, allanamientos, detenidos, heridos y un asesinato en la calle; por lo general son trabajadores anónimos, sólo las víctimas portan su nombre en el funeral.

${ }^{4}$ Medina, “iIdentidad?”, 1994, pp. 592-593.

${ }^{5}$ Luis Príamo dice: "los reporteros gráficos de Caras y Caretas utilizaron desde el principio el formato pequeño de la época, es decir, el $9 \times 12 \mathrm{~cm}$ con cámaras portátiles y ágiles y mucha libertad para el encuadre, la iluminación o la pose de las personas, casi siempre imprevisibles y determinados por los propios acontecimientos más que por la voluntad del fotógrafo. La habilidad con que dominaban la luz ambiente en interiores de talleres, oficinas, galpones es notable." Príamo, "Fotografía", 2000, pp. 182-184.

${ }^{6}$ Los distintos grupos anarquistas, frecuentemente, organizaron picnics en los que se desarrollaban actividades culturales y recreativas a fin de atraer a los trabajadores y estimular la ideología ácrata. 
Hacia principios del siglo xx la fotografía ha recorrido un camino que reconoce distintos usos, ha comenzado a circular entre los individuos de distintos sectores sociales y se ha instalado, gracias a algunos medios gráficos, como forma de denuncia pública. ${ }^{7}$ La representación fotográfica se convierte en una herramienta capaz de expresar, construir y difundir los debates de la "opinión pública" que está en vías de consolidación y es tenida en cuenta por las elites gobernantes. En la tapa de un número de Caras y Caretas de 1902, una caricatura revela el alcance de la opinión pública en este periodo: el presidente Julio A. Roca está inclinado sobre una mujer que duerme plácidamente, en su vestido lleva escrito "opinión pública". A su lado, hay un mosquito que en sus alas dice "partido liberal". El hombre dice: "iLa vi agitarse! Si no le espanto de algún modo, el inoportuno mosquito acabará por despertármela". ${ }^{9}$ Es decir, que el partido liberal puede despertar la opinión pública que no favorece al presidente.

También para los sectores populares, la exposición pública de los conflictos es un modo fundamental de participación y las fotografías indican que las demandas de los sectores populares están bien despiertas, más cerca del desvelo que de la plácida bella durmiente.

Muchos de los trabajadores retratados muestran, con obviedad, los periódicos a la cámara (véase foto 1). Este hecho refuerza la idea de la amplia difusión de la prensa obrera, ${ }^{10}$ pero indica también el uso y conocimiento de la publicidad para transmitir consignas como "protesta", huelga o boicot; una lucha de "vanguardia" y la importancia de la "organización obrera". Al mismo tiempo permite observar una "extraordinaria vocación de visibilidad" propia de esta época. ${ }^{11}$

Entre 1860 y 1880, la expansión de la prensa, la proliferación de las asociaciones, y los actos y manifestaciones fueron prácticas que se desarrollaban en el seno de una esfera pública en construcción y dieron forma a una "cultura de la movilización". ${ }^{12}$ Estas acciones podían tener dis-

${ }^{7}$ Es interesante destacar la sección de Caras y Caretas "Paseos fotográficos por el municipio", en la cual se incluyen denuncias de calles rotas o edificios abandonados, así como parodias a los vendedores ambulantes y sus pregones. Véase, por ejemplo, revista Caras y Caretas, 26 de abril de 1902.

${ }^{8}$ En este trabajo se utiliza "opinión pública" en el sentido que le da Habermas, se trataba de formar una opinión pública capaz de impulsar la vida política y estaba orientada por la existencia de un periodismo independiente. Habermas, Historia, 1986.

${ }^{9}$ Caras y Caretas, año v, núm. 195, 28 de junio de 1902 sin numeración de páginas.

${ }^{10}$ Véase, por ejemplo, Ciboti, "Habitante", 2000, t. 5, pp. 365-408.

${ }^{11}$ Como sugiere R. Cicerchia: "Los diarios efectivamente desplegaron discursos políticos, pero más importante aún, ofrecieron palabras e imágenes a una comunidad cada vez más amplia." Cicerchia, Historia, 2001.

${ }^{12}$ Hilda Sábato ha propuesto la idea de una cultura de la movilización como forma de participación política. Explica que la forma más común de hacer escuchar una opinión o establecer un reclamo o demanda era a través de una declaración o petitorio. La acción colectiva solía culminar en una asamblea interna o en una demostración pública exterior. Sábato, Política, 1998. 
tintos propósitos, pero su objetivo principal era subrayar la fuerza, demostrar a la opinión pública y a las autoridades que grupos numerosos apoyaban una misma causa. Las fotografías de principio de siglo forman parte de estas prácticas que se utilizan, junto a los actos y movilizaciones, para exhibir los reclamos.

La selección de un conjunto de imágenes muestra las distintas etapas de organización de las manifestaciones. En los locales se organizan las asambleas y allí se distingue un mundo iconográfico de ciertos grupos de trabajadores. Papeles y tinta china sobre los escritorios, en el fondo una gran bandera con la espiga de trigo y el mundo bordados construyen el escenario propio de la Sociedad Cosmopolita de Resistencia de Panaderos. En el local de la sociedad cosmopolita de obreros-pintores hay varias imágenes: un retrato de Marx y dos escudos con banderines (véase foto 2). En la foto del allanamiento a un centro cosmopolita han quedado colgados en la pared distintos papeles y recortes de diarios, fotografías, un almanaque y unos cuadros. Uno de los cuadros es una alegoría: un murciélago con cabeza de calavera y tentáculos de pulpo despliega sus alas sobre una mujer semirrecostada con el pecho desnudo; al fondo, unas figuras de los poderes burgueses miran disimuladamente hacia otro lado; al pie, fuera del cuadro se puede leer "capitalismo" (véase foto 3). A veces los locales se comparten, como sucede en la asamblea de los cigarreros de 1904, que transcurre en el local de la sociedad cosmopolita de obreros pintores (véase foto 2). Otras veces se improvisa el centro de reunión, utilizando un patio $y$, cuando las circunstancias lo permiten, se usa un teatro (véanse fotos 1 y 4 ).

La puerta de la Casa Obrera Gremial convoca a los trabajadores que posan para la foto o muestra el ir y venir de los agremiados (véase foto 5). En las calles y plazas transcurren las manifestaciones (véase foto 6), son los ámbitos públicos por antonomasia y dependen del tipo de reclamo dónde se localicen: la Plaza Once, Constitución y Lavalle reúnen las manifestaciones del 1 de mayo; la Plaza del Congreso es para presionar al poder legislativo en los momentos de decisiones políticas; el mercado y el puerto demuestran el carácter económico de las reivindicaciones, así como la efectividad y la fuerza de presión de las huelgas. En las huelgas de 1902 y 1904 predomina la quietud, la paralización de las actividades del mercado de frutos es pacífica; los trenes cargados, detenidos en La Boca, a la espera de la reanudación de las actividades. Hacia el final de la década, los enfrentamientos armados en la calle muestran el choque, los heridos, el fuego y las barricadas.

Se puede decir que la ciudad es el ámbito donde se exponen los conflictos, así es que la Federación Agraria Argentina en una muestra de gran movilización y convocatoria organizó una manifestación que se iniciaba 
en la ciudad de Santa Fe y concluía en la de Buenos Aires. Circuló en forma pacífica y ordenada, por cientos de kilómetros, desde distintos puntos de la región pampeana hasta llegar al frente del Congreso Nacional. ${ }^{13}$

Algunos artículos de Caras y Caretas relativos a reclamos y manifestaciones destacan la importancia de la propaganda para aumentar la adhesión, llamar la atención de la ciudadanía, la intervención gubernamental, y alcanzar así mejores resultados. Por ejemplo, a partir de enero de 1904 , los dependientes de comercio lograron que los negocios cerraran sus puertas los días domingo, obteniendo así el solicitado descanso dominical. En febrero de ese año, Caras y Caretas publica otra nota, explicando la organización de los fotógrafos para obtener el descanso dominical: "la agrupación de fotógrafos designó una comisión para que lleve a cabo los trabajos de propaganda en pro de esa idea. Esta comisión se pondrá al habla con la de dependientes de comercio a fin de unir los esfuerzos de unos y otros para la realización de un fin que mejore la situación de todos." ${ }^{14}$ La propaganda cumple una función importante en el marco de la organización entre distintas agrupaciones y para obtener respuestas a los reclamos.

En el caso de la huelga de inquilinos de 1907 que reclamaba una disminución de los precios de alquiler, la prensa cubrió con amplitud los sucesos. ${ }^{15}$ Se comentaban las malas condiciones de vida, las medidas del gobierno y los acontecimientos diarios que protagonizaban los participantes del conflicto. Entre ellos los más destacados eran las luchas entre policías y mujeres en los desalojos. Incluso La Protesta se permitió destacar un acontecimiento que provoca una sonrisa:

En la calle Defensa existe un conventillo cuyo encargado quiso sentar plaza de hombre guapo, golpeando bárbaramente a un muchacho de tierna edad [...] Las valerosas mujeres, después de derribarlo al suelo impidiéndole todo movimiento, se les ocurrió la humorada de quitarle los calzones, largándolo en tal facha a la calle, provocando la risa de todos los espectadores de este curioso y divertido sainete. ${ }^{16}$

Asimismo, hubo un hecho que mereció la atención y del cual existen algunas fotos: la marcha de las escobas. En su gran mayoría niños y mujeres recorrieron las calles del barrio de La Boca levantando las escobas

${ }^{13}$ Como dice Mirta Lobato: "La manifestación por las calles de la ciudad dio estado público a sus demandas. El monumento a Cristóbal Colón frente a la casa de gobierno, la avenida de Mayo y la Plaza del Congreso fueron el escenario donde se hizo visible la presencia de sus cuerpos junto al alegato de los números. Los chacareros fueron uno de los sujetos rurales que expresaban su descontento en el espacio de la ciudad." Lobato, "Cine", 2000, p. 7.

${ }_{14}$ Caras y Caretas, 6 de febrero de 1904, sin numeración de páginas.

${ }^{15}$ Para una ampliación sobre el tema de la huelga de inquilinos véase Suriano, Huelga, 1983.

${ }^{16}$ La Protesta, 12 de octubre de 1907, citado por Spalding, Clase, 1970, pp. 481-483. 
"para barrer a los caseros". Es interesante señalar el papel simbólico de la escoba como instrumento fundamental que se utilizó para manifestar un problema esencial, ya que los alquileres representaban una alta proporción del salario de los trabajadores. ${ }^{17}$ La utilización de un tipo de fuentes como las fotografías analizadas en este trabajo demuestran que la presencia femenina es insoslayable, al mismo tiempo que los niños ocupan el protagonismo de la primera fila ${ }^{18}$ (véanse fotos $2,4,5$ y 9 ). Dejando de lado a algunas niñas que pueden estar acompañando a sus madres o a chicos que quieren aparecer en las fotografías, hay una buena proporción de niños que llevan su ropa de trabajo o que aparecen como lectores de los periódicos de la organización obrera. En una fotografía de la asamblea general de los cigarreros, en 1904, sobre un total de 29 huelguistas hay once niños y una niña; dos de ellos tienen un periódico y uno, además de anteojos, usa su delantal de trabajo (véase foto 2). Parecería ser que en las huelgas los niños tienen asignadas tareas específicas como la lectura y el reparto de manifiestos y periódicos a otros trabajadores. Estos documentos no aportan datos cuantificables pero, además de afirmar la inocultable presencia femenina y de los niños, expresan ciertas actitudes de orgullo y desafío que se reflejan en las poses de los jóvenes trabajadores.

En este mundo en confrontación, el cuerpo, las manos y la vestimenta muestran códigos y signos mediante los cuales los trabajadores comunican algunos de sus valores. Con una forma claramente codificada, la mano con el índice extendido señala el titular de un periódico, un cartel con el titular de "boicot" o una $\mathrm{H}$ en una bandera" ${ }^{19}$ (véase foto 9 ).

Las fotografías de las huelgas de 1902 y 1904, publicadas en Caras y Caretas, evidencian cierta simpatía hacia los trabajadores. Quisiera sugerir que hasta este momento "las reuniones públicas se consideraban una práctica benéfica de las instituciones democráticas [...] resultado del uso del derecho de reunión pacífica [...] establecido por la Constitución y las

${ }^{17}$ En 1886 el alquiler representaba 16\% del salario de jornaleros y artesanos, en 1912 representaba 30\%. Scobie, Centro, 1977.

${ }^{18}$ En un artículo sobre el trabajo de los niños, Juan Suriano explica la ausencia de este tema en las ciencias sociales debido a la carencia de fuentes que hagan posible el estudio del trabajo infantil. De todas formas, a partir de datos fragmentarios logra establecer algunas cifras significativas. En 1904, la población infantil de Buenos Aires de seis a quince años era de 208418 niños, sólo $12.8 \%$ eran analfabetos, aunque se desconoce el grado de instrucción del resto y 7191 menores de 16 años estaban ocupados en la industria de la Capital Federal. Se puede asegurar que no menos de $3.4 \%$ de los niños trabajaban en la industria. Suriano llega a la conclusión que los niños eran contratados por las habilidades para actividades que requerían más destreza que fuerza, para el trabajo como auxiliares o en tareas complementarias, y por su docilidad y obediencia. Suriano, "Niños", 1990, pp. 251-279.

${ }^{19} \mathrm{El}$ dedo índice que señala se dibujaba frecuentemente en las propagandas junto a inscripciones como "sépalo usted" y luego se describían los productos señalados. 
leyes de la república" ${ }^{20}$ En una huelga de estibadores y frigoríficos en Zárate, junto a las fotos el cronista asegura que "la actitud de la masa era pacífica y correcta". ${ }^{21}$ Asimismo, el texto que se incluye en una de las notas de 1904 está firmado por Alberto Ghiraldo, periodista afín al anarquismo. Este autor destaca la solidaridad, la organización y la libertad de discusión entre los trabajadores "que tanta consistencia ha dado a los gremios en lucha". ${ }^{22}$ Una mirada a través de las fotografías nos lleva a pensar que muchos trabajadores eran conscientes de la necesidad de evitar disturbios. Para la mayor eficacia de las huelgas no se debía transgredir ese "orden" ciudadano. Los socialistas insisten en señalar "que nuestras manifestaciones son modelos de educación y cultura", ${ }^{23}$ también los gremios anarquistas muestran la lucha pacífica que se puede observar a través de distintos gestos. Existen varias fotografías del momento de discusión y redacción de los pliegos de condiciones (véanse fotos 2 y 10). Es evidente que la foto no es una instantánea del momento exacto de los acontecimientos decisivos, pero la pose armada para la fotografía enfatiza aún más el uso de recursos legales, como la redacción de petitorios escritos, para reclamar los derechos por vía pacífica. Las imágenes acentúan la percepción de un mundo del trabajo, caracterizado por la organización, solidaridad y fuerza de los conflictos para mejorar las condiciones laborales. ${ }^{24}$

En 1919, Caras y Caretas ha cambiado sustancialmente la opinión acerca de los huelguistas. Un artículo denominado la "Semana Trágica" pretende relatar la narración de los acontecimientos a través de 91 fotos y quince dibujos, insistiendo en los disturbios iniciados por grupos con ideologías revolucionarias. El texto que acompaña las imágenes es una larga justificación periodística:

La crónica gráfica es siempre fiel; pero, para recoger todos los hechos producidos, hubiera sido necesario que hubiesen entrado en acción todas las máquinas fotográficas de Buenos Aires y eso hubiera sido peligroso para los fotógrafos; habrían aumentado el número de muertos y heridos, dadas las intenciones de los revoltosos contra los discípulos de Daguerre. ${ }^{25}$

${ }^{20}$ Hilda Sábato considera que al menos hasta 1890 las manifestaciones públicas eran un derecho político. Sábato, Política, 1998, p. 184.

${ }^{21}$ Caras y Caretas, año v, núm. 216, 22 de noviembre de 1902, sin numeración de páginas.

${ }^{22}$ Caras y Caretas, año vil, núm. 276, 16 de enero de 1904, sin numeración de páginas.

${ }^{23}$ La Vanguardia, 1 de mayo de 1909, citado por Viguera, "Primero", 1991, pp. 53-79.

${ }^{24} \mathrm{~J}$. Suriano señala que "es indudable la existencia de este costado violento en la conmemoración del 1 de mayo que no anula el marco del orden, sugerido por Viguera, en el que se realizaban los actos anarquistas. Orden y violencia no necesitan estar separados necesariamente". Suriano, "Banderas", 1997, p. 95.

${ }^{25}$ Caras y Caretas, año XXII, nūm. 1059, 18 de enero de 1919, sin numeración de páginas. 
La justificación es necesaria, las ametralladoras están en manos de la policía, los reporteros llegan tarde a los "actos de vandalismo", faltan los protagonistas "exaltados", las calles aparecen desiertas y sólo queda un poco de humo. Los periodistas gráficos de la Semana Trágica pueden ser incluidos en una concepción dominante, que consideraba la emergencia de los conflictos como el resultado de una acción premeditada de "minorías subversivas" ${ }^{26}$ Las metáforas de enfermedades sociales hacen pensar en la influencia de la criminología lombrosiana.$^{27} \mathrm{El}$ artículo de Caras y Caretas veía la causa de los disturbios en "la imposición que los ácratas propalan" y espera que "el gobierno tomará medidas oportunas para curarnos de esta plaga" ${ }^{28}$ Incluso llegan a sostener que "por dolorosa experiencia sabemos que los huelguistas revolucionarios son enemigos de la fotografía" ${ }^{29}$ Esta afirmación es sorprendente, el gremio anarquista de panaderos se caracterizó por la fuerza de su lucha; sin embargo, durante las huelgas de 1902 y 1911, los fotógrafos ingresaban en las asambleas, los fotografiaron y luego publicaron sus imágenes, insistiendo en ciertos aspectos positivos de los reclamos (véase foto 2).

En el periodo analizado (1902-1919), las fotografías son una herramienta más de expresión de discursos en confrontación y muestran cómo los trabajadores definen su descontento. Hacia principios del siglo xx los resultados son alentadores. Las fotos de la paralización de actividades evidencian, también desde un punto de vista simbólico, la importancia de los obreros. Se obtiene el descanso dominical, los industriales organizan la Unión Industrial Argentina para contrarrestar el peso de la organización de los trabajadores. ${ }^{30}$ El Estado debe intervenir en la creación de leyes y en la represión. El conflicto se agudiza, pero los trabajadores son conscientes de la importancia de la propaganda y expresan sus necesidades también a través de la prensa y de la fotografía.

En esta percepción del mundo se reconoce la conciencia de la visibilidad pública. Distintas asociaciones y oficios, así como los diversos grupos ideológicos consideran importante hacerse ver y mostrar los símbolos de identificación. Con este propósito, también la fotografía es un instrumento útil para desplegar esa voluntad de visibilidad. Ya en 1902, se retratan las asambleas, los meetings, se muestran a cámara los periódi-

${ }^{26}$ Acerca de las reflexiones sobre los conflictos surgidos en el mundo del trabajo entre los sectores políticos e intelectuales de la clase dirigente argentina véase Sidicaro, Política, 1993, p. 29.

${ }^{27}$ Cesare Lombroso inauguró la escuela de antropología criminal. El italiano consideraba que los caracteres físicos y somáticos de ciertos adultos delincuentes los predisponían al crimen. Las medidas del cuerpo determinaban las medidas morales del alma. Estas ideas formaban parte de la ideología darwinista social que relacionaba los aspectos biológicos con los sociales.

${ }^{28}$ Caras y Caretas, año XXII, núm. 1059, 18 de enero de 1919, sin numeración de páginas.

${ }^{29} \mathrm{Ibid}$.

${ }^{30}$ Véase Rocchi, "Largo", 2000, pp. 159-190. 
cos. De alguna manera se conforma un escenario a ser retratado, sabiendo que será reproducido en los periódicos.

Estos documentos han permitido observar diversas formas de solidaridad: el intercambio de locales; las ollas populares para los trabajadores en huelga; el uso, lectura, difusión y exposición a cámara de los periódicos; los picnics y los reclamos por la libertad de los compañeros. La organización y solidaridad, la lectura de la prensa obrera, las banderas y la ideología, así como las fotografías forman parte de los recursos apropiados y exhibidos, en la búsqueda de mejores condiciones de vida y de trabajo. Para que el reclamo permanezca hay que hacerlo visible, definiendo qué mostrar. Existe una disputa por la definición de los significados, ¿quién inicia la violencia?, ¿es conveniente utilizarla o es mejor enfatizar el "orden"? La fotografía ha colaborado a esclarecer cómo son esos significados en pugna.

En cuanto a las características metodológicas asumidas, a partir de las discusiones existentes en torno al mundo del trabajo se ha procedido a la observación directa de las fotografías. Se pudieron percibir distintos ámbitos de lucha, características de actores involucrados, formas y cultura de la movilización, gestos y símbolos habituales. A través del análisis de la publicación, los epígrafes y los textos en relación con las fotos, se estudió el contexto. ${ }^{31}$ Paradójicamente, de 1902 a 1907 los trabajadores logran trascender y mostrar un mundo rico y propio, mientras que en 1919 Caras y Caretas impone un sentido despectivo, manipulado y unívoco de las huelgas y manifestaciones.

Resistencia, transgresión, "orden", negociación y conflicto forman parte del mundo del trabajo que es fotografiado, a veces intencionalmente, otras por la irrefrenable dinámica de la prensa. Los reclamos analizados no sólo se expresan en los momentos de conflicto, se mantienen al igual que el retrato de Marx o los recortes de diario en la pared, como símbolo de que la resistencia también puede ser pacífica y cotidiana.

${ }^{31}$ Boris Kossoy distingue entre el análisis técnico-iconográfico para conocer los elementos constitutivos de la propia imagen y la interpretación iconológica referida al contexto, que permite reconstruir los eslabones ausentes en las fotografías. Véase Kossoy, Fotografía, 2001. 


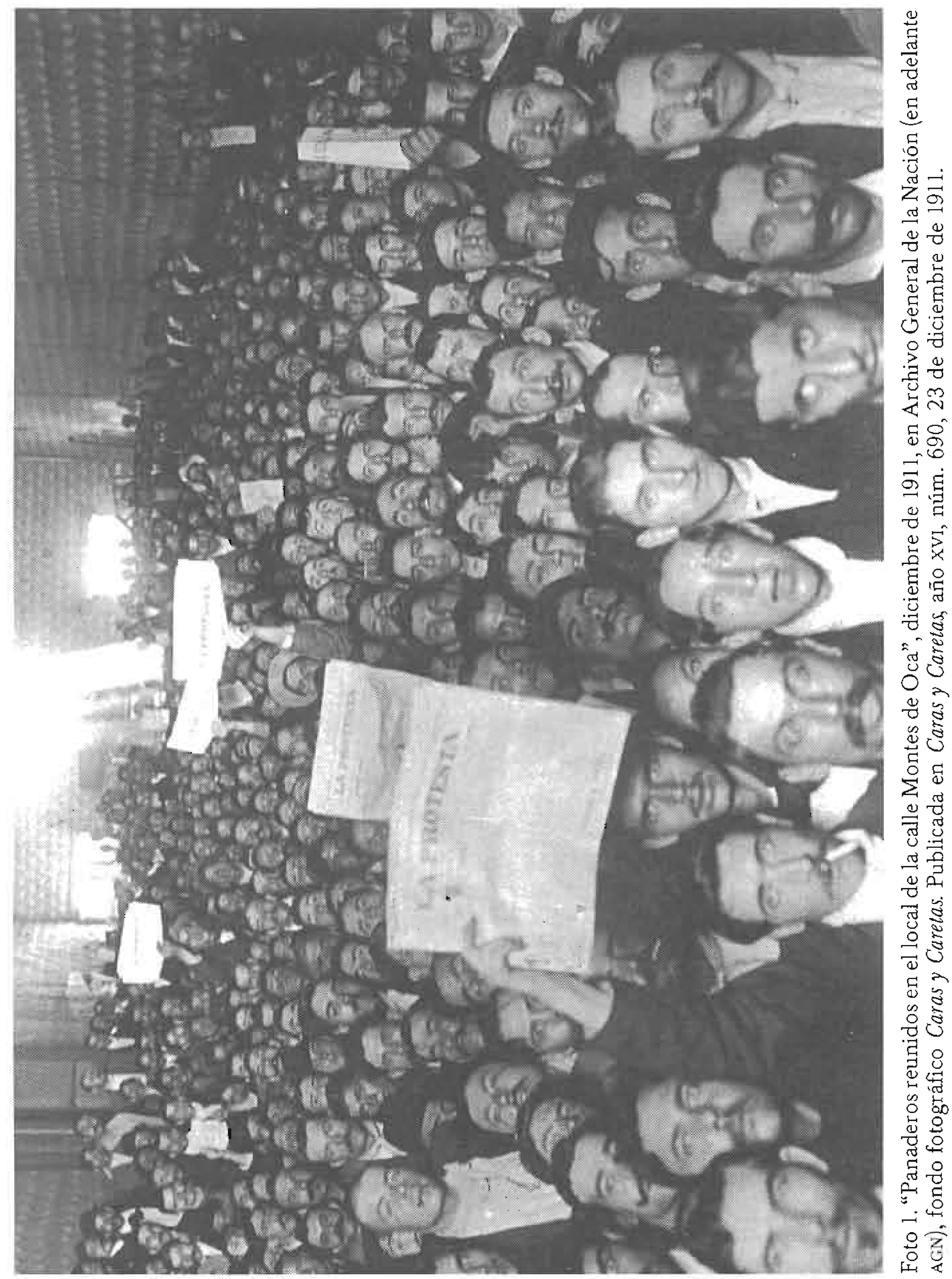




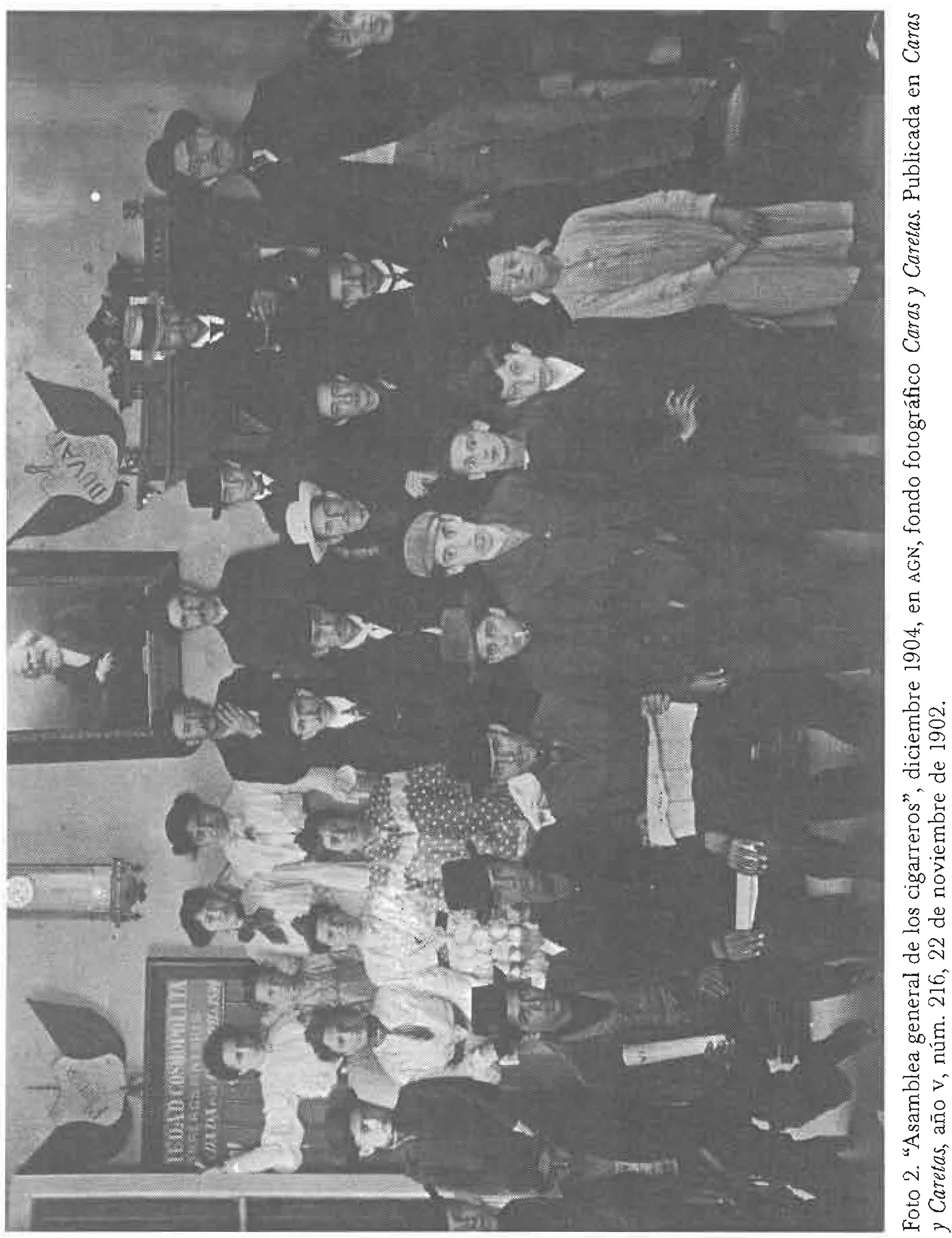




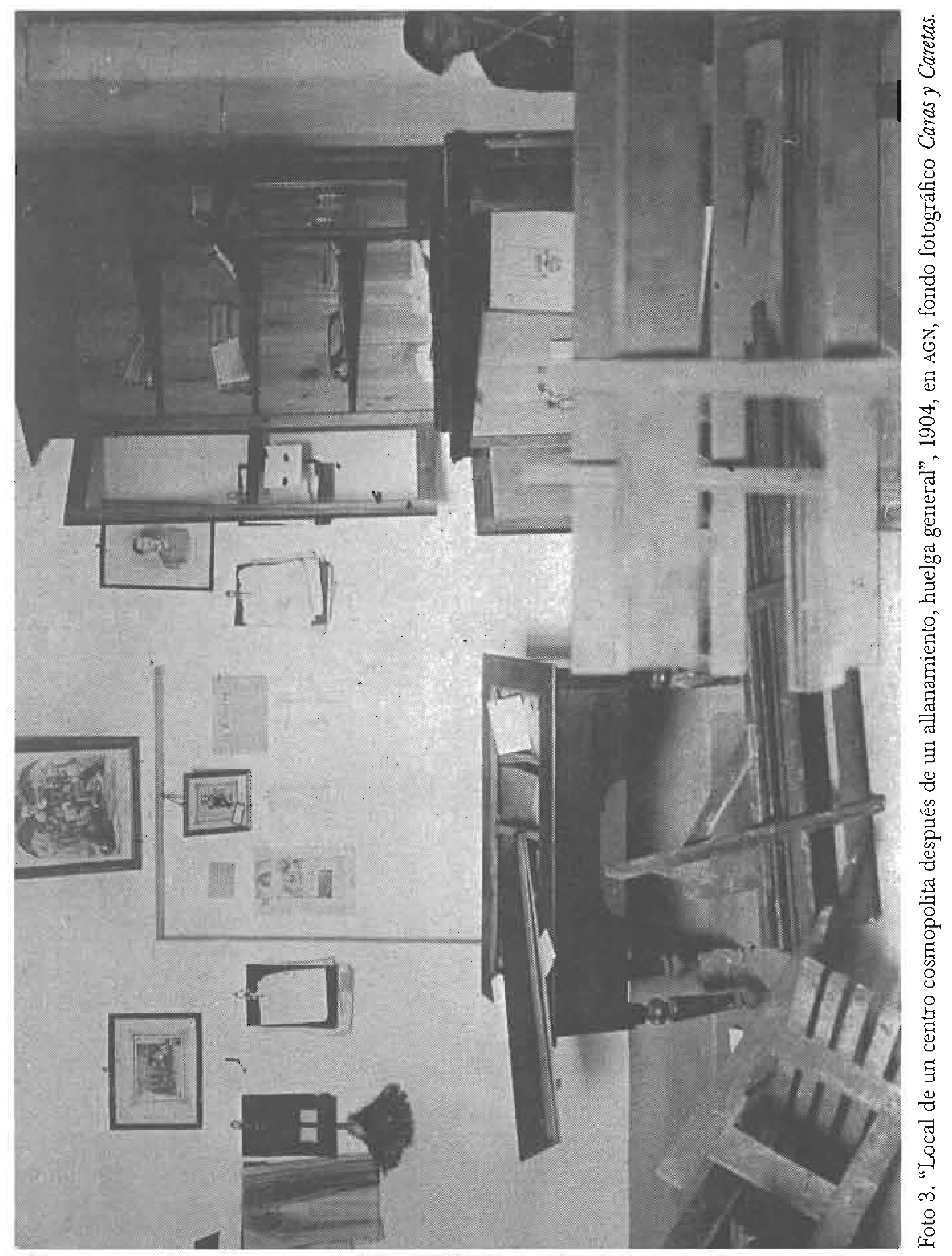




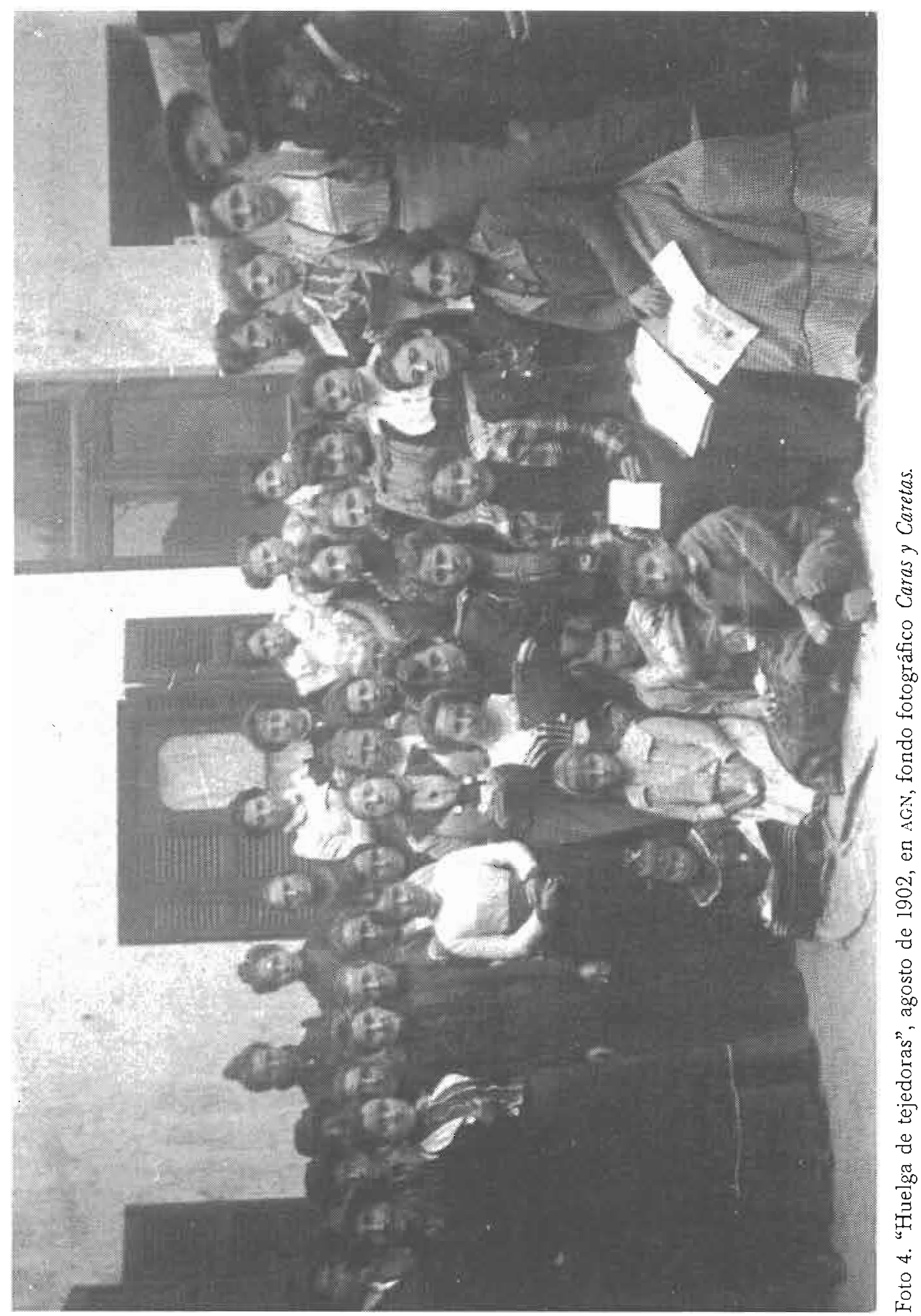




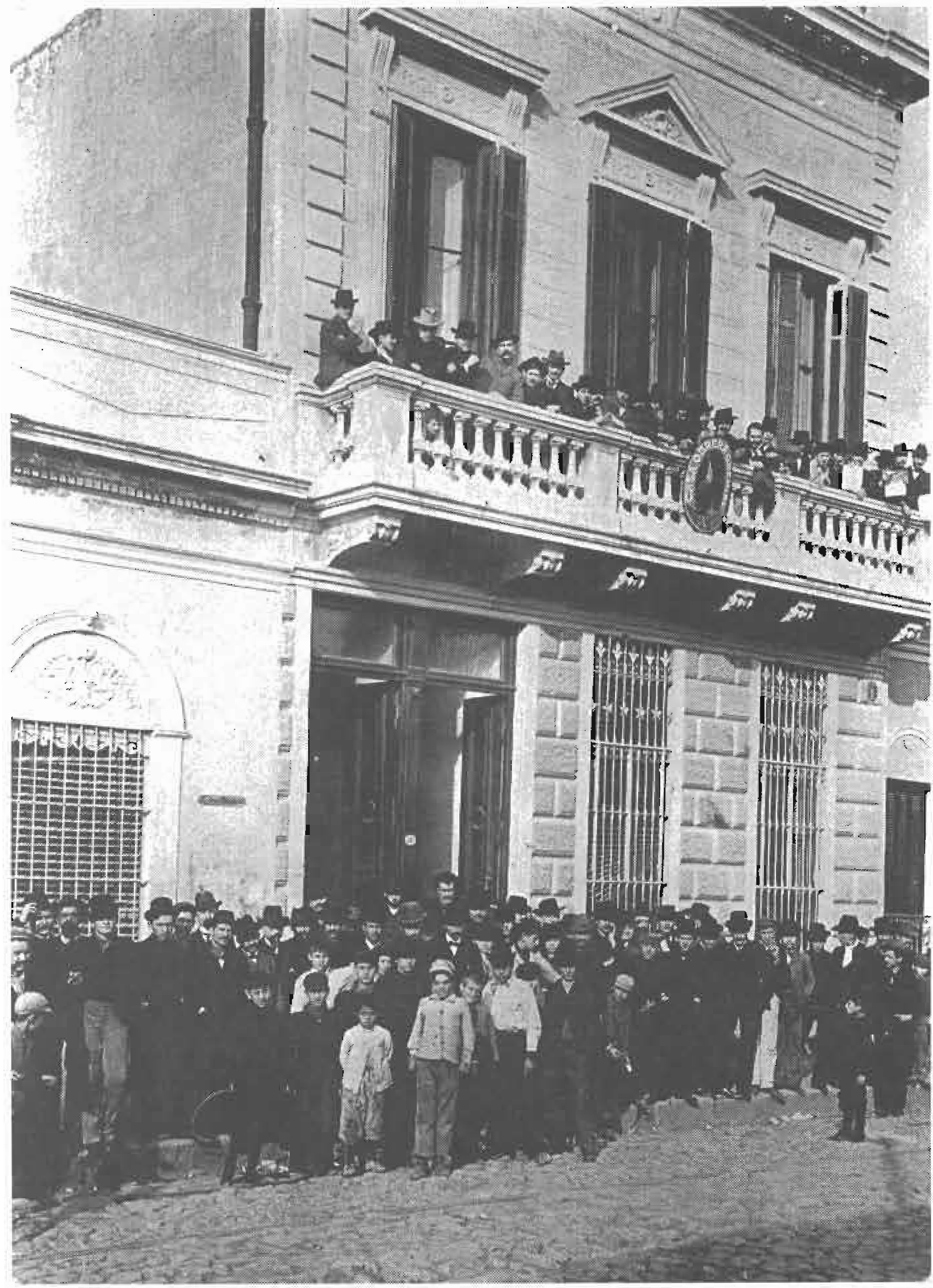

Foto 5. "Huelga de zapateros", 1907, en AGN, fondo fotográfico Caras y Carelas. 


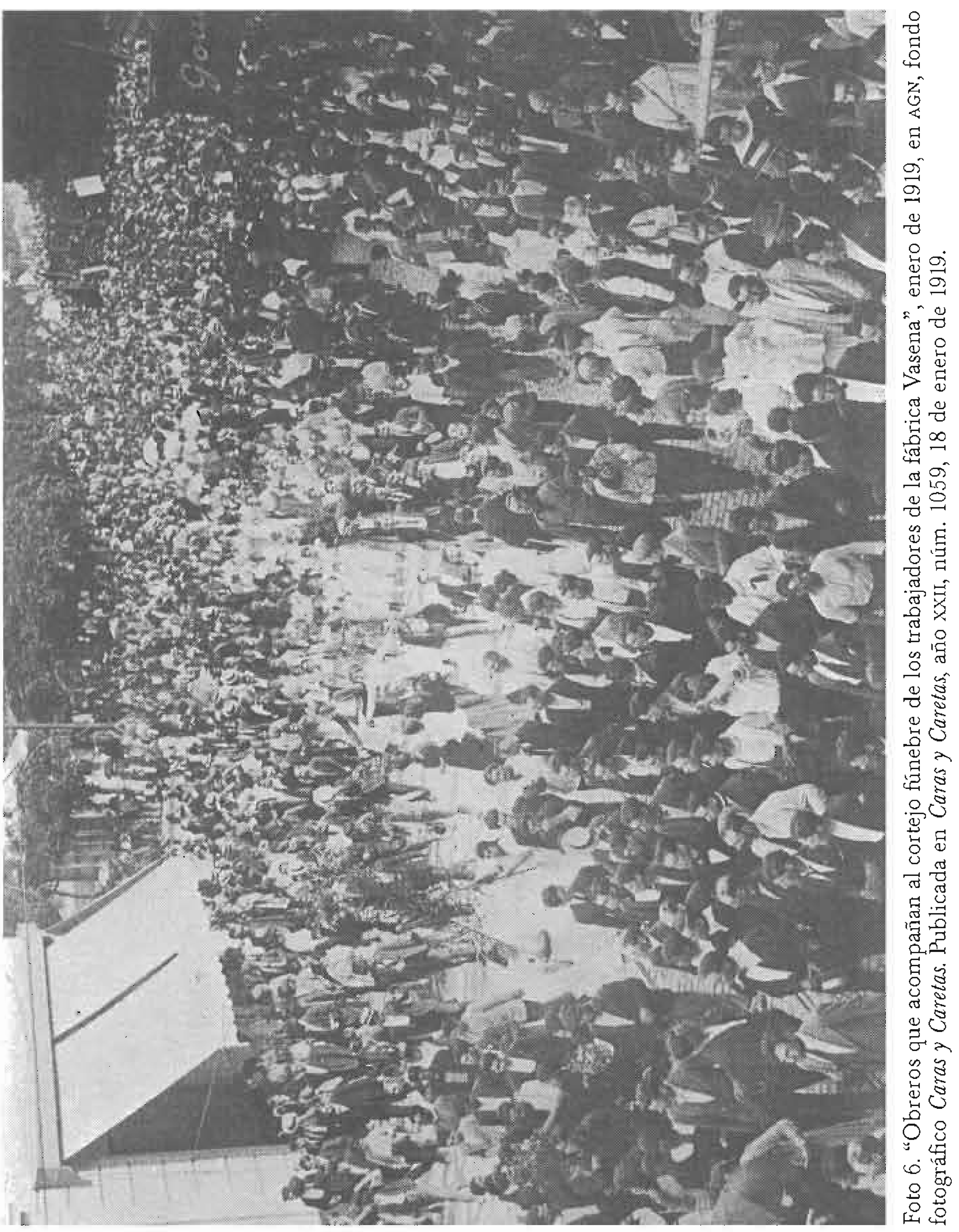




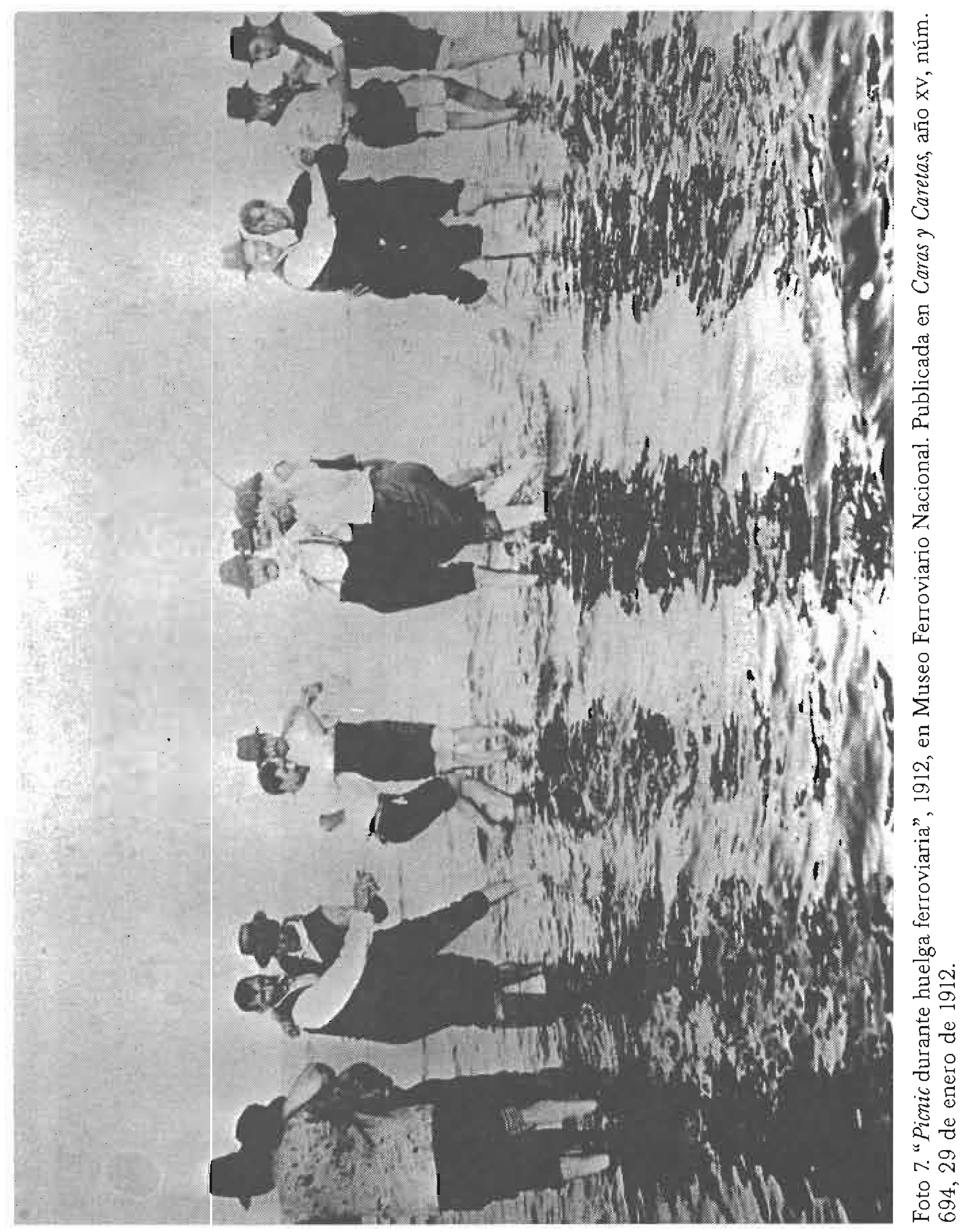




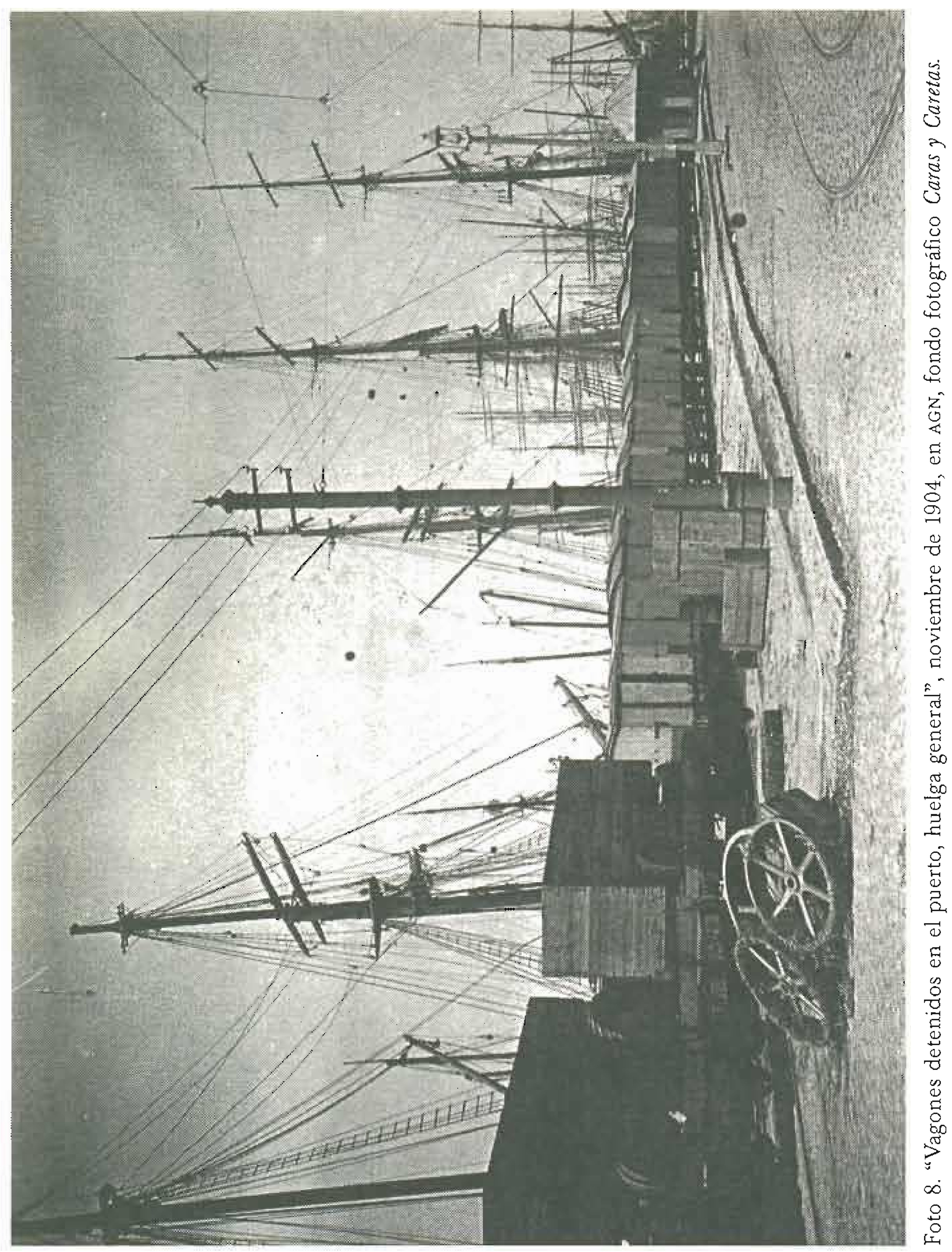




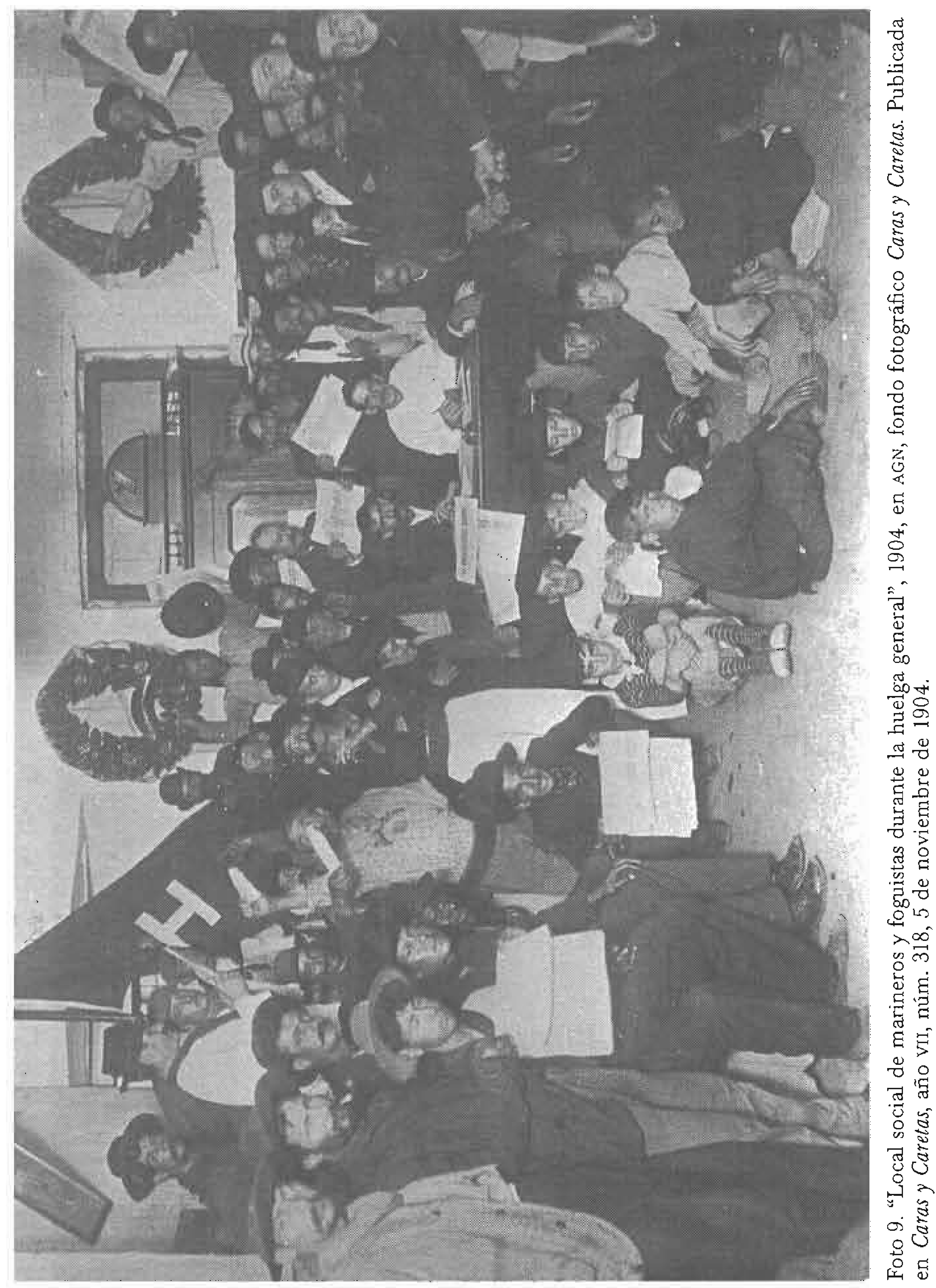




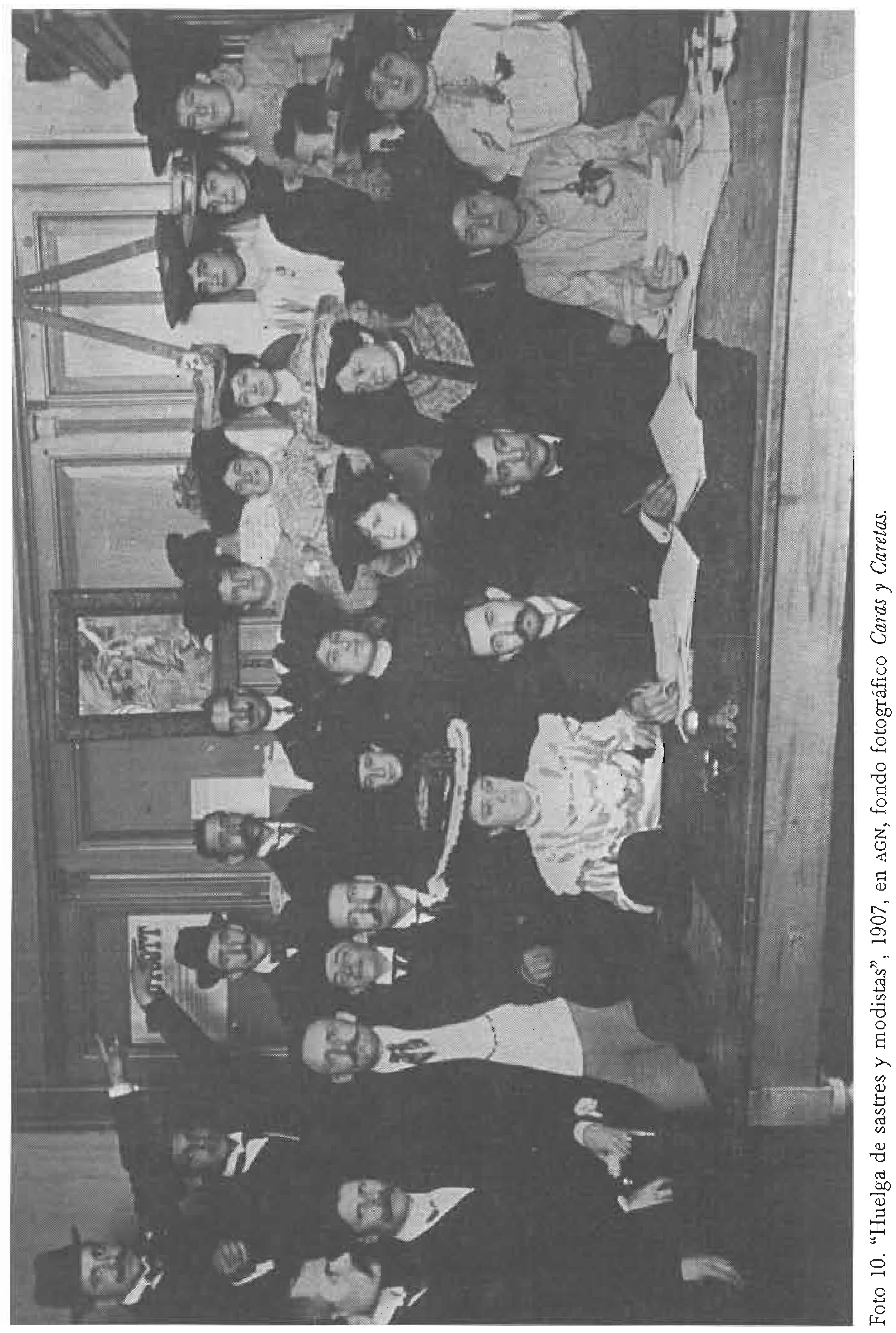




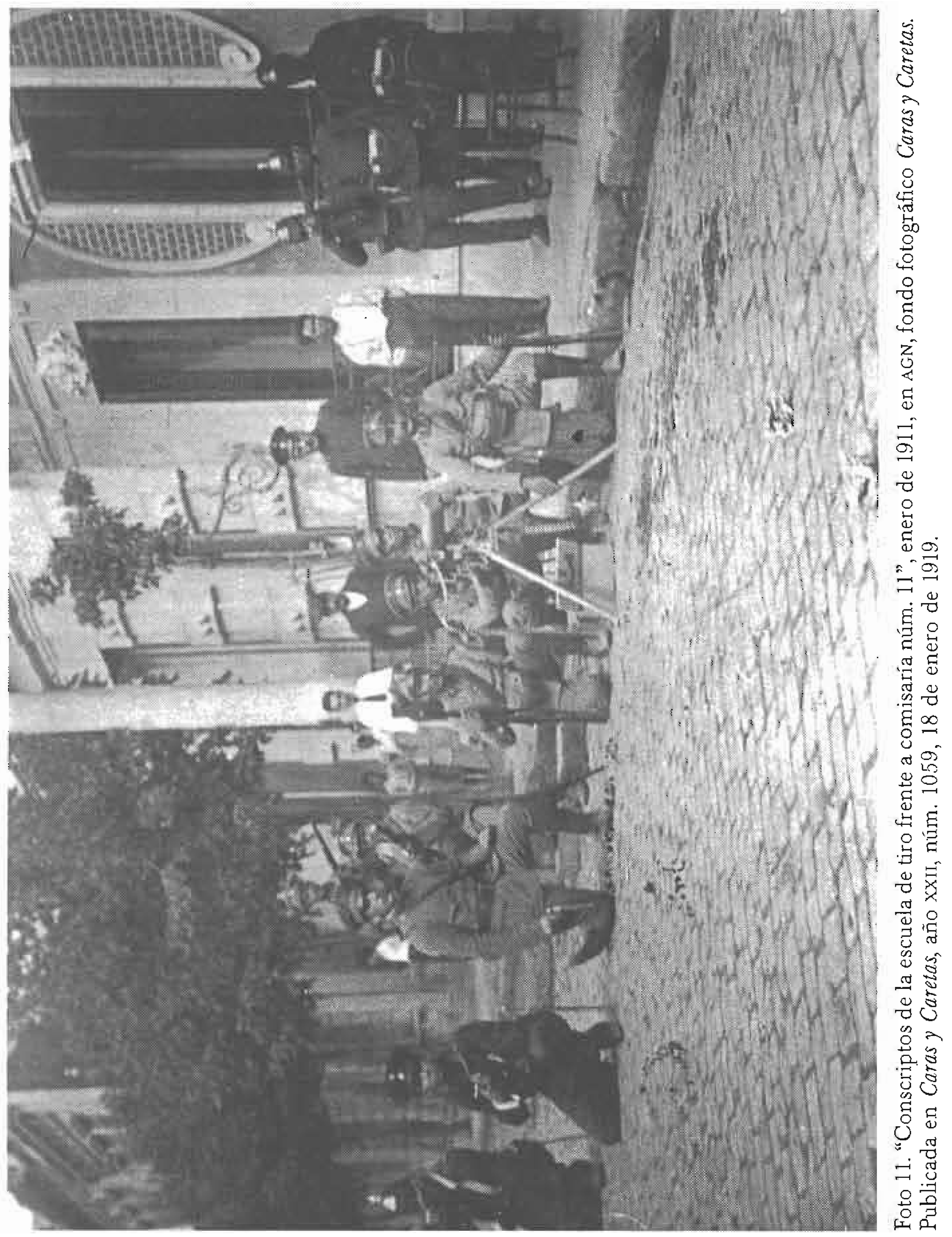




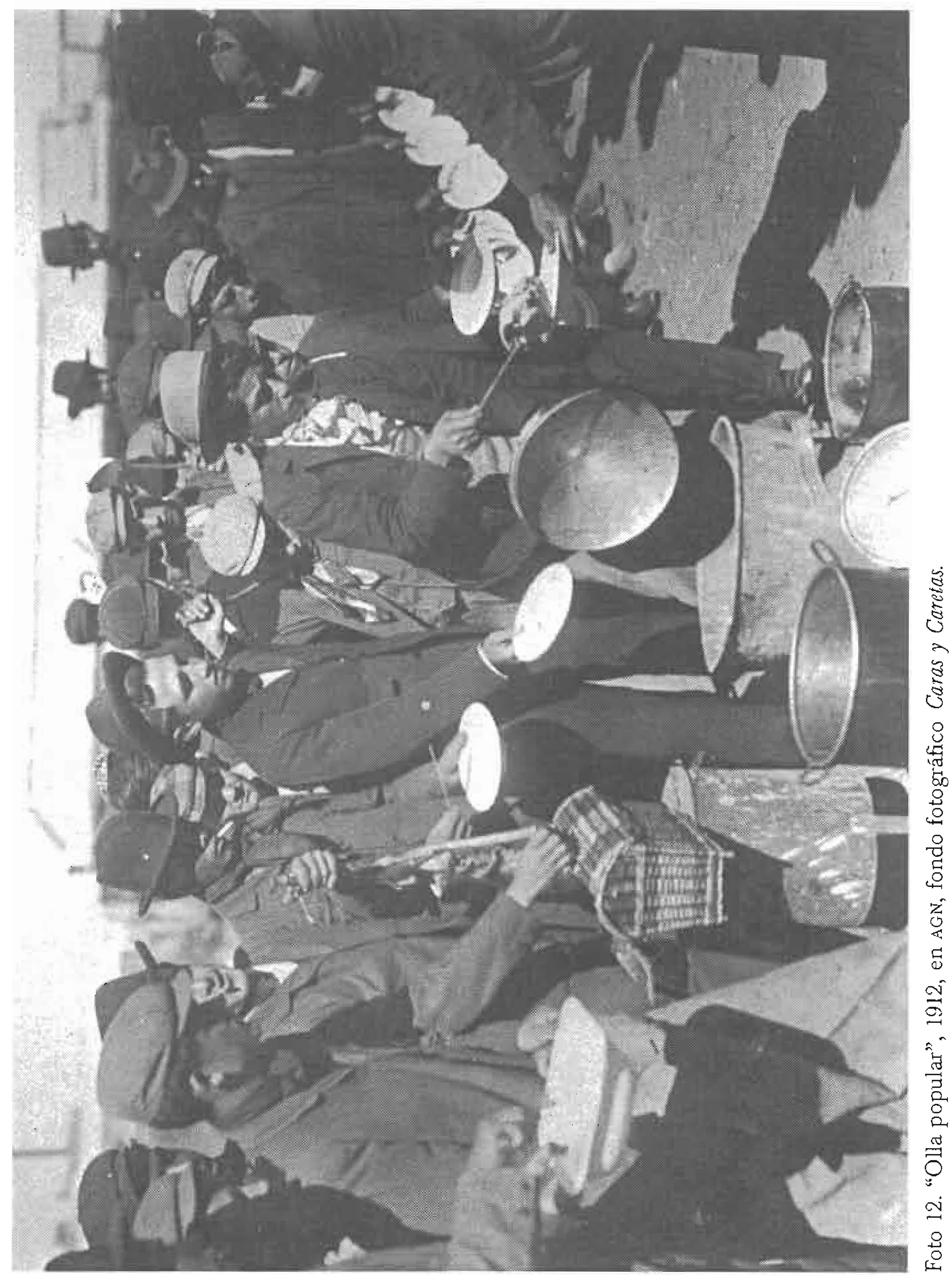




\section{Archivos}

AGN Archivo General de la Nación, Argentina, Biblioteca Nacional de Argentina.

\section{BIBLIOGRAFÍA}

Altamirano, Carlos, "Lo imaginario como campo del anâlisis histórico y social", Punto de Vista, núm. 38, año XIII, octubre de 1990, pp. 11-14.

Amigo Cerisola, Roberto, "Imágenes para una nación. Juan Manuel Blanes y la pintura de tema histórico en la Argentina" en Arte, historia e identidad en América Latina. Visiones comparativas. XVIII Coloquio Internacional de Historia del Arte, México, UNAM, 1994, pp. 315-331.

Andreu, Jean, Maurice Fraysse y Eva Golluscio de Montoya, Anarkos. Literaturas libertarias de América del Sur 1900, Buenos Aires, Corregidor, 1990.

BACZKo, BRonislaW, Los imaginarios sociales. Memorias y esperanzas colectivas, Buenos Aires, Nueva Visión, 1999.

Berger, John, Mirar, Buenos Aires, Ediciones de la Flor, 1998.

Buenos Aires 1910: memoria del porvenir, Buenos Aires, IIED-América Latina, 2000.

Bustos, Liliana, "Caras y Caretas de la memoria" en Historia de la Fotografía Memoria del V Congreso de Historia de la Fotografía en la Argentina, Buenos Aires, 1997.

CHARTIER, ROGER, El mundo como representación. Historia cultural entre práctica y representación, Barcelona, Gedisa, 1992.

Ciвoti, Ema, "Del habitante al ciudadano: la condición del inmigrante" en MirTa Z. Loвato, Nueva historia argentina, Buenos Aires, Sudamericana, 2000, 8 tt., pp. $365-408$.

CiCERCHIA, RiCARDo, Historia de la vida privada en la Argentina. Desde la Constitución de 1853 hasta la crisis de 1930, Buenos Aires, Troquel, 2001.

Cichero, Marta (idea y dir. ed.), Producción y trabajo en la Argentina. Memoria fotográfica 1860-1960, Buenos Aires, Universidad Nacional de Quilmes/Banco BICE, 2002.

Fernández, JuAn R., Historia del periodismo argentino, Buenos Aires, Círculo de la Prensa, 1943.

Fotografie Lateinamerika von 1860 bis heute, Zürich, Kunhaust, 1981.

FrydenberG, Julio y Miguel Ruffo, La semana roja de 1909, Buenos Aires, Centro Editor de América Latina, 1992.

Galván Moreno, Carlos, El periodismo argentino, Buenos Aires, Claridad, 1944.

Geli, Patricio, "Los anarquistas en el gabinete antropométrico. Anarquismo y criminología en la sociedad argentina del 900", Entrepasados, núm. 2, 1992.

Gutman, Margarita y Thomas Reese (eds.), Buenos Aires 1910: el imaginario para una gran capital, Buenos Aires, Eudeba, 1999. 
HABERMAS, JÜRGEN, Historia y crítica de la opinión pública. La transformación estructural de la vida pública, México, Gilli, 1986.

HOBSBAWM, ERIC, El mundo del trabajo. Estudios históricos sobre la formación y evolución de la clase obrera, Barcelona, Crítica, 1987.

Kossoy, Boris, Fotografia e historia, Buenos Aires, La Marca/Biblioteca de la Mirada, 2001.

LOBATO, MirTa Z., "El cine en la narrativa nacional: En pos de la tierra y la movilización chacarera de 1921", Entrepasados, núms. 18 y 19, año IX, 2000, pp. 7-24. La vida en las fábricas. Trabajo, protesta y política en una comunidad obrera, Berisso (1904-1970), Buenos Aires, Entrepasados/Prometeo Libros, 2001.

MEdina, CuAuHTÉmoc, “ ¿identidad o identificación? La fotografía y la distinción de las personas. Un caso oaxaqueño" en Arte, historia e identidad en América Latina. Visiones comparativas. XVIII Coloquio Internacional de Historia del Arte, México, UNAM, 1994, pp. 577-597.

MirÁs, MARTA, "Sociedad Fotográfica Argentina de Aficionados: una mirada sobre Buenos Aires", Historia de la Fotografía Memoria del V Congreso de Historia de la Fotografía en la Argentina, Buenos Aires, 1997.

Mraz, John, Nacho López y el fotoperiodismo mexicano en los años cincuenta, México, Océano/CONACUlTA-INAH, 1999. , "Una historiografía crítica de la historia gráfica", Cuicuilco, vol. 5, núm. 13, mayo-agosto de 1998, pp. 77-92.

PanetTieri, José (comp.), Argentina: Trabajadores entre dos guerras, Buenos Aires, Eudeba, 2000.

Penhos, Marta N., "La fotografía del siglo XIX y la construcción de una imagen pública de los indios" en El Arte entre lo Público y lo Privado, VIJornadas de Teoría e Historia de las Artes, Buenos Aires, Centro Argentino de Investigadores de Arte, 1995, pp. 109-126.

Pignatelin, Adrian I., "Caras y Caretas" en Historia de las revistas argentinas, Buenos Aires, Asociación Argentina de Editores de Revistas, 1997, t. II, pp. 271-348.

PitTALUgA, Roberto, "Un imaginario utópico-restaurador en el anarquismo de la Argentina", El Rodaballo, núms. 11 y 12, primavera de 2000.

Pool, Deborah, Vision, Race and Modernity. A Visual Economy of the Andean Image World, Nueva Jersey, Princeton University Press, 1997.

PRíAmo, Luis, Archivo fotográfico del ferrocarril de Santa $F e, 1891 / 1948$, Buenos Aires, Fundación Antorchas, 1994. Juan Pi Fotografias, 1903/1933, Buenos Aires, Fundación Antorchas, 1994. "Fotografía y periodismo", Buenos Aires 1910: memoria del provenir, Buenos Aires, Instituto Internacional de Medio Ambiente y Desarrollo-América Latina, 2000, pp. 182-184. Vistas de la provincia de Santa Fe, 1888-1892. Fotografias de Ernesto H. Schlie, Santa Fe, Argentina, Editorial Diario El Litoral, 2000. 
RoCCHI, FERNANDo, "Un largo camino a casa: empresarios, trabajadores e identidad industrial argentina, 1880-1930 en JUAN SURIANO (comp.), La cuestión social en Argentina, 1870-1943, Buenos Aires, La Colmena, 2000, pp. 159-190.

RUIBAL, BEATRIZ, "El control social y la policía de Buenos Aires, Buenos Aires, 18801920", Boletín del Instituto de Historia Argentina y Americana Dr. Emilio Ravignani, tercera serie, núm. 2, primer semestre de 1990.

SÁBATO, HILDA, La política en las calles. Entre el voto y la movilización, Buenos Aires, 18621880, Buenos Aires, Sudamericana, 1998.

SAMUEL, RAPHAEL, "El ojo de la historia", Entrepasados, año 9, núms. 18 y 19, 2000, Buenos Aires, pp. 145-170.

SCOBIE, JAMES, Del centro a los barrios, 1870-1910, Buenos Aires, Solar/Hachette, 1977.

Sidicaro, RiCARDo, La política mirada desde arriba. Las ideas del diario La Nación, 1909-1989, Buenos Aires, Sudamericana, 1993.

Spalding, Hobart, La clase trabajadora (Documentos para su historia 1880-1912), Buenos Aires, Galerna, 1970.

Suriano, JuAn, La huelga de inquilinos de 1907, Buenos Aires, Centro Editor de América Latina, 1983.

Trabajadores, anarquismo y Estado represor: de la Ley de Residencia a la Ley de Defensa Social (1902-1910), Buenos Aires, Centro Editor de América Latina, 1988. "Niños trabajadores. Una aproximación al trabajo infantil en la industria porteña de comienzos de siglo" en DiEgo ARMUS (comp.), Mundo urbano y cultura popular, Buenos Aires, Sudamericana, 1990, pp. 251-279.

"Estado y conflicto social: el caso de la huelga de maquinistas ferroviarios de 1912", Boletin del Instituto de Historia Argentina y Americana Dr. Emilio Ravignani, tercera serie, núm. 4, segundo semestre de 1991, pp. 91-115.

"Banderas, héroes y fiestas proletarias. Ritualidad y simbología anarquista a comienzos del siglo", Boletín del Instituto de Historia Argentina y Americana Dr. Emilio Ravignani, tercera serie, núm. 15, primer semestre de 1997, pp. 71-99. (comp.), La cuestión social en Argentina 1870-1943, Buenos Aires, La Colmena, 2000.

Streik, Realitat und Mythos, Berlin, Deutsches Historisches Museum, 1992.

Thompson, EdWARd Palmer, The Making of the English Working Class, Estados Unidos, Vinatge, 1966. Costumbres en común, Barcelona, Crítica, 1995.

VÁzQUeZ-RIAL, HoRAcio (dir.), Buenos Aires 1880-1930. La capital de un imperio imaginario, Madrid, Alianza Editorial, 1996.

Viguera, ANíbal, "El primero de mayo en Buenos Aires, 1890-1950: evolución y usos de una tradición", Boletín del Instituto de Historia Argentina y Americana Dr. Emilio Ravignani, tercera serie, núm. 3, primer semestre de 1991, pp. 53-79. 